Corresponding Author:

Ahmad Faridi

Received: 18 August 2019

Accepted: 25 August 2019

Published: 29 August 2019

Production and Hosting by Knowledge E

(c) Ahmad Faridi et al. This article is distributed under the terms of the Creative

Commons Attribution

License, which permits

unrestricted use and

redistribution provided that

the original author and

source are credited.

Editor-in-Chief:

Dr. Dimitrios Papandreou

Official Publication of Zayed University, UAE

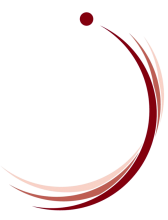

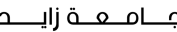
ZAYED UNIVERSITY
Research Article

\section{The Effect of Training Mothers on Modifying the Meal Boxes of their Preschoolers with Vegetables and Fruits in the Sub-district of Tangerang, Tangerang City, Banten Province}

\section{Ahmad Faridi ${ }^{1}$, Tifani Larasati ${ }^{2}$, Asri Werdhasari ${ }^{3}$, and Kenti Friskarini ${ }^{4}$}

${ }^{1}$ Faculty of Public Health, Program Study Nutrition, The University of Muhammadiyah Prof. Dr. Hamka (UHAMKA), Jakarta Indonesia

${ }^{2}$ Staff of Selambaran Jaya Community Health Center (PUSKESMAS) Tangerang City, Banten, Indonesia

${ }^{3}$ Research and Development for Biomedis of Basic Health Technologies, Ministry of Health Republic of Indonesia

${ }^{4}$ Research and Development for Public Health, Ministry of Health Republic of Indonesia

\section{Abstract}

Background: Preschooler is a group who is at risk of having low-interest in consuming fruits and vegetables. The low-consumption of vegetables in children is influenced by the mother's lack of knowledge and incomplete composition of food. One way to improve vegetables and fruits consumption was through training in modifying meal box. Objectives: This study purposed at determining the effect of Modifying Meal Box Training to Increase Vegetables and Fruits Consumption for Preschool Children. Method: This study used a quasi-experimental research method with pre-test and post-test control group design. Involving 40 mothers who took their children to school, this study conducted in the Pengayoman Kindergarten and Trisula Kindergarten in Tangerang City. The results of statistical tests showed that there were differences in knowledge before and after the intervention in the control group and the treatment group. Results: However, after the intervention there was no significant difference in knowledge in the control group and the treatment group with $p$ value of 0.770 . There were differences in food composition and consuming vegetables and fruits before and after the intervention in the treatment group. On the other hand, there were no differences in consuming vegetables and fruits consumption before and after intervention in the control group. After the intervention had been given, there was no significant difference in knowledge in the control group and the treatment group with $p$ value of 0.270 . Conclusions: Nevertheless, there are differences in the level of knowledge in the control group and the treatment group.

Keywords: Training, Nutrition Knowledge, Meal Box, Vegetables and Fruits Consumption, Preschool Age 


\section{Introduction}

Fruits and vegetables are food sources which are rich in vitamins and minerals that are very beneficial for health, development and growth. Although the needs are relatively small, the function of vitamins and minerals can hardly be replaced so that the consumption of these substances is essential. Fruit and vegetables are very important to be consumed, especially for children, preschoolers in particular. However, nowadays children tend to consume less fruits and vegetables, while fruits and vegetables are very useful as a source of accomplishing good nutritional needs [1-3].

The consumption of vegetables and fruits give advantages in reducing the risk of degenerative diseases such as cardiovascular, cancer, hypertension and so on (Almatsier, 2009). Zuraida (2015) stated that there was a relationship between the consumption of vegetables and fruits with cardiovascular disease $(p=0.001)$ and consumption of vegetables and fruit were protective factors against cardiovascular disease $(O R=0.83)$. The data of WHO (2003) showed that $31 \%$ of heart disease and $11 \%$ of stroke were caused by low consumption of vegetables and fruits.

There is a correlation between vegetable consumption and the incidence of obesity in school-age children, as in the study conducted by Daruwati (2017) which stated that there is a relationship between consumption of vegetables and fruits and obesity as shown by $p=0.005$ and $O R=7.273$. Additionally, the lack consumption of vegetables and fruits risks seven times of obesity.

The consumption of vegetables and fruits in children is still very minimal and there are still many who are not in accordance with the recommendations. According to the Balanced Nutrition Guidelines (2014), for toddlers and school-age children it is recommended to consume 300-400 grams of vegetables and fruits consisting of 250 grams of vegetables and 150 grams of fruit. The 2007 Basic Health Research (Riskesdas) resulted that generally only 3.3 percent of the population aged 10 years and over in Banten Province consumed enough vegetables and fruits. Almost all residents (96.7\%) consume less vegetables and fruits. Based on research conducted by Basic Health Research (Riskesdas) in 2013, the prevalence of less consumption of vegetables and fruits of the people of Indonesia is still at 93.5\%. Indeed, the prevalence in West Java Province is $96.4 \%$.

The prevalence of lack of vegertables and fruits consumption in preschool children is quite significant. The data from the research conducted by Paboyo (2012) showed that only $29.6 \%$ of preschoolers in Canada consume fruits and vegetables which in 
accordance with food guidelines in Canada. In the United States of America, at 2014, $31.5 \%$ of preschoolers consumed vegetables and fruits less than the recommendation of adequacy while 80.3\% consume less vegetable (Krebs, 2010 in Harnack, et al, 2012, D. Upton, 2012, Kirsten, 2014, Eun. 2018).

In Indonesia, the average consumption of vegetables and fruits of the Indonesian population is 108.8 grams/person/day. Specifically, based on the age group, the least consumer of vegetables and fruits was children under five years old (79.4 grams/person/day) and based on the results of the average analysis of the total consumption of vegetables and fruits of the population was 195.4 grams/person/day. In fact, the minimum consumption of vegetables and fruits for the children under-five group is 138.0 grams/person/day (SKMI in the Total Diet Study, 2014).

The low consumption of vegetables and fruits in preschoolers is because of the desire of parents to meet nutritional needs in children often leads to the improper feeding practices, 25\%-50\% parents are incorrectly carrying out feeding practices (Powel, Farrow and Mayer (2011).

The habit of bringing meal to school is inseparable from the mother's role in determining the amount, type, and variation of food. According to Meliala's research (2014) which shows that mothers provide meal box at most in the form of biscuits by $30 \%$, the second highest meal box is rice and side dishes, which is $22 \%$. The types of side dishes prepared by the mother for the meal box for children in school are eggs, chicken, tempeh and fish. The drink prepared by the mother the most is mineral water (86\%).

According to Notoatmodjo (2010), nutrition counseling is carried out to broaden the mothers' knowledge about the consumption of vegetables and fruits. The materials and messages conveyed are easy to understand and more interesting. Then, the training is an activity that will produce behavioral changes and improve the mothers' skills. Also, media can avoid misperceptions, clarify information, facilitate understanding, reduce verbalistic communication, and facilitate communication. The five senses that distribute knowledge to the brain are the eyes (approximately $75 \%$ to $87 \%$ ), while $13 \%$ to $25 \%$, human knowledge is obtained and channeled through the other five senses (Kapti, 2010). 


\section{Methods}

\subsection{Research Design}

The research design used in this study was Quasi Experiment through pretest-posttest with control group design. The intervention group was the group that received intervention (treatment), while the control group was a group that did not receive any intervention from the researcher. Moreover, the data collection was done in both groups.

\subsection{Population and Sampel}

The target population in this study was all students in Class A in Pengayoman Islamic Kindergarten and Trisula Kindergarten in the City of Tangerang in 2018. The population of this study was the students of Pengayoman Islamic and Trisula Kindergarten who were registered as students in Class $A$. The probability sampling techniques was used with a purposive sampling approach that is based on the criteria preferred by researchers (Nursalam, 2013). The samples used in this study were all students of Pengayoman Islamic Kindergarten and Trisula Kindergarten who were registered as students in Class $A$ that met the criteria of the researcher.

\subsection{Data Collection}

The data in this study consisted of the characteristics of respondents by observing the data on mothers' knowledge of nutrition, the data on the composition of meal box by conducting observations, the data on vegetables and fruits consumption in meal box and the intervention data, through training.

\subsection{Data Processing and Analysis}

The data was based on the characteristics of respondents (age, number of family members, preferences of vegetables and fruits), the composition of meal box (consisting of staple foods, animals or vegetables dishes, vegetables and fruits), the data of vegetables and fruit consumptions, specifically the consumption of vegetables and fruits at the children's meal box and the data on mothers' knowledge on nutrition about vegetables and fruits. The data was analysed to determine whether or not there was a difference in nutritional knowledge, and consumption of vegetables and fruit before 
and after counseling based on the results of pre-test and post-test in the treatment and control groups using the "Wilcoxon" method. Meanwhile, to examine differences in food composition based on the results of pre- test and post-test in the control group and treatment group, the "Chi-Square" test was used. Moreover, to determine whether or not the effect of meal box modification, training intervention was carried out, a different test was conducted if the data were normally distributed using the "Independent Sample $t$ Test" method.

\section{Result}

\subsection{Characteristics of Respondents Before the Intervention}

The characteristics of respondents in this study consisted of age, number of family members, and preferences on vegetables and fruits.

TABLE 1: Frequency Distribution on Characteristics of Mothers' Age, Number of Family Members, Nutrition Knowledge and the Consumption of Vegetables and Fruits of Inter-Group Respondents.

\begin{tabular}{|l|c|c|c|c|c|c|}
\hline Variable & Group & N & Mean & SD & $\begin{array}{c}\text { Minimum - } \\
\text { maximum }\end{array}$ & Value p \\
\hline Mother's Age & Treatment & 20 & 35 & 7,056 & $20-46$ & 0.411 \\
\hline & Control & 20 & 35,25 & 5,954 & $20-50$ & 0,814 \\
\hline Number of Family Members & Treatment & 20 & 4,30 & 0,923 & $3-7$ & $3-6$ \\
\hline & Control & 20 & 4,50 & 1,00 & $50-95$ & 0,016 \\
\hline $\begin{array}{l}\text { Mother's Knowledge on } \\
\text { Nutrition }\end{array}$ & Treatment & 20 & 80,25 & 13,025 & 50 & \\
\hline & Control & 20 & 85,25 & 6,584 & $70-95$ & 0,463 \\
\hline $\begin{array}{l}\text { Consumption of } \\
\text { Vegetables and Fruits }\end{array}$ & Treatment & 20 & 25,00 & 44,42 & & $0,00-100$ \\
\hline
\end{tabular}

Table 1 presented the characteristics of the respondents included the mother's age, number of family members, preference for vegetables, preference for fruits, composition of meal box and consumption of vegetables and fruit did not differ in the treatment and control groups before the intervention. However at the level of knowledge there are differences in the treatment group and the control group which can be seen from the bigger score in the control group than in the treatment group.

Based on the characteristics of age in table 1, the age of the mother in the intervention group and the control group averaged 35 years. According to Faryati (2012), a person with an age range $<26$ years is classified in the young category, while $26-40$ years is classified in the adult category and age $>40$ years is classified in the old category. 
TABLE 2: Frequency Distribution on the Characteristics of Vegetables and Fruits Preferences of the Respondents among Groups.

\begin{tabular}{|l|c|c|c|}
\hline Characteristics & Control Group & $\begin{array}{c}\text { Treatment } \\
\text { Group }\end{array}$ & $\mathbf{P}$ \\
\hline Preference on Vegetables & $\mathrm{n}(\%)$ & $\mathrm{n}(\%)$ & \\
\hline Like & $15(75)$ & $17(85)$ & 0,695 \\
\hline Dislike & $5(25)$ & $3(15)$ & \\
\hline Total $\mathbf{n}(\%)$ & $20(100)$ & $20(100)$ & \\
\hline Preference on Fruits & & $17(85)$ & 0.100 \\
\hline Like & $16(80)$ & $3(15)$ \\
\hline Dislike & $4(20)$ & $20(100)$ & \\
\hline Total $\mathbf{n}(\%)$ & $20(100)$ & &
\end{tabular}

In table 2, based on the level of preference, it was shown in the treatment group and the control group that most children liked vegetables and fruits. $85 \%$ children in the treatment group like vegetables and fruits. At the beginning of the study, there were no differences in characteristics shown from the level of preference for vegetables and fruit in the two groups.

TABLE 3: Distribution of Food Composition in Inter-Group Meal Box.

\begin{tabular}{|l|c|c|c|}
\hline Characteristics & Control Group & Treatment Group & p \\
\hline Food Composition & $\mathbf{n}(\%)$ & $\mathbf{n}(\%)$ & \\
\hline Complete & $2(10)$ & $4(20)$ & 0,661 \\
\hline Incomplete & $18(90)$ & $16(80)$ & \\
\hline Total $\mathbf{n}(\%)$ & $20(100)$ & $20(100)$ & \\
\hline
\end{tabular}

Table 3 shows that the composition of food was mostly in the treatment group and the majority control group provided incomplete meal box. Most mothers provided only carbohydrates and animal protein, such as rice + nuggets and noodles + nuggets. It can be concluded that at the beginning of the study there were no differences in characteristics seen from the composition of food supplies in both groups.

\subsection{Knowledge on Nutrition}

\subsubsection{Distribution of Knowledge Nutrition by Group}

Graph 1: below shows changes the score of intervention on knowledge nutrition in each group. 


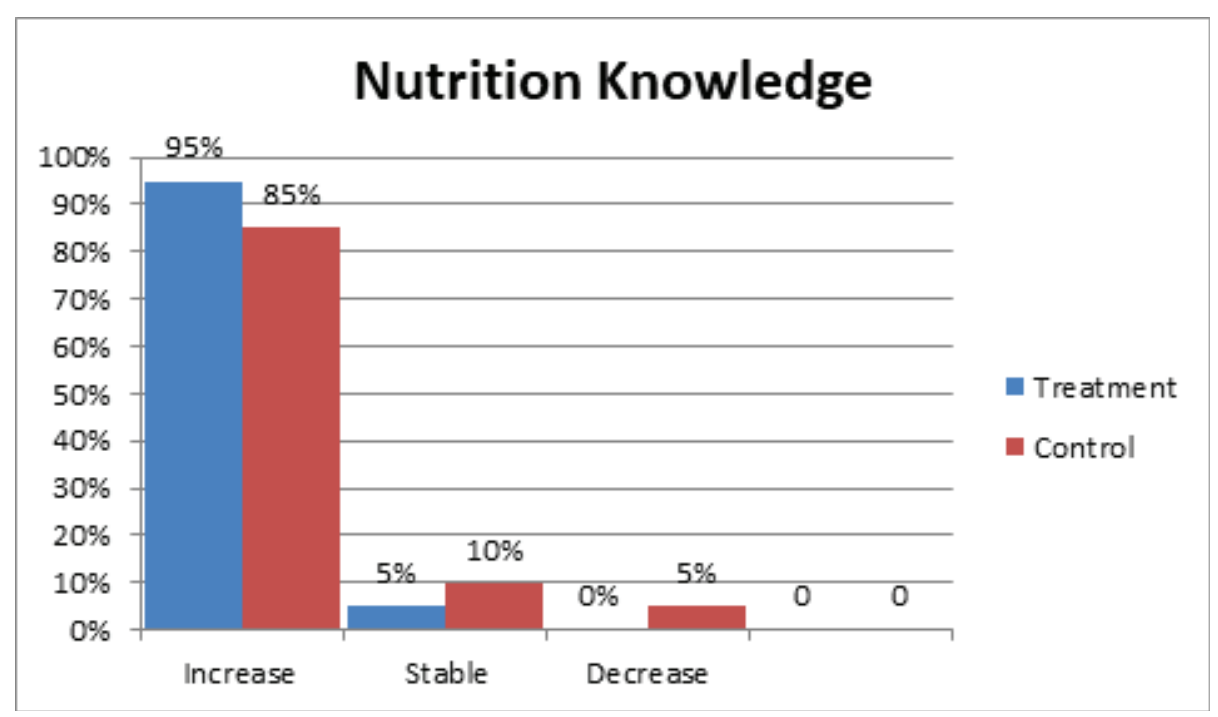

Figure 1: Graph of Changing Score Frequency Distribution in Nutrition Knowledge by Group.

In Figure 1, the knowledge score increased more in the treatment group than in the control group. In the control group, there was still a knowledge score that decreased. The increasing knowledge in the treatment group occured because besides getting counseling and material that can be read at home, respondents in the treatment group also get repeated information every day when researchers observed meal box, so that respondents have better understanding clearly. Thus, ask directly if there is material that is not understood or want to find out. In line with the study of Jayani et al., 2011 which stated that the repetition of the information and the frequency of the test can help the process of entering information into long-term memory.

\subsubsection{The Effect of Training on Modifying Meal Box towards the Chang- ing of Mother's Knowledge in the Treatment Group and Control Group}

TABLE 4: Knowledge Differences Before and after Counseling in the Treatment and Control Group.

\begin{tabular}{|l|c|c|c|c|c|}
\hline Variable & Group & $\mathbf{n}$ & \multicolumn{2}{|c|}{ Median (K1-K3) } & p Value \\
\hline Knowledge & & Before & After & \\
\hline & Treatment & 20 & $85(71,25-90)$ & $95(95-100)$ & 0,000 \\
\hline & Control & 20 & $85(80-90)$ & $95(95-100)$ & 0,000 \\
\hline
\end{tabular}


TABLE 5: Knowledge Differences After Group Counseling.

\begin{tabular}{|l|c|c|c|c|}
\hline Variable & Group & N & Median (K1-K3) & p Value \\
\hline Knowledge & Treatment & 20 & $95(95-100)$ & 0,770 \\
\hline & Control & 20 & $95(95-100)$ & \\
\hline
\end{tabular}

\section{Mann Whitney Test}

In the table 4 , based on the Wilcoxon test, the result of $p$ value $0,000(<0.05)$ was obtained. Therefore, it can be concluded that there were differences in knowledge of respondents before and after the intervention in the treatment group and the control group. Whereas, the total knowledge score experienced 10 points of improvement after being given intervention. The different types of interventions given in both groups made a difference in nutritional knowledge scores. In the other words, the counseling on nutrition knowledge has an effect on increasing respondents' knowledge.

Hence, this was because the control group and the treatment group have had counseling equally through power point before the intervention so that there was a significant difference in scores before and after counseling in both groups. Transferring information through a program providing nutrition education interventions can improve one's knowledge, and consumption of vegetables and fruits (Pem, 2015). Suhardjo in Dewantari (2011) said that education is one of the efforts to overcome nutritional problems. Within the improvement of nutrition education, it is expected that there will be a change in the behavior of food consumption and nutritional status.

In table 5, the results obtained which based on the Mann Whitney test was $p$ value of $0.770(<0.05)$. Thus, it can be concluded that there was no significant difference in the average knowledge of respondents in the control group and treatment group after the counseling had been given.

On this research, mothers in the treatment group and the control group have the same counseling before the intervention. Henceforth, both groups experienced the same good knowledge before the intervention so that when the counseling was conducted by researchers, the knowledge scores in the two groups changed significantly. However, there was no difference in knowledge of respondents after having counseling.

The results of this study are in line with the research conducted by Friel S, Kelleher C in Nuryanto et al (2014) in which the results of the study showed that there was no significant differences regarding nutritional knowledge after obtaining nutrition education for 3 months in both the intervention group and control group. There was no significant 
difference in the study because the level of nutrition knowledge of the respondents before the intervention was good enough.

On the other hand, the results of this study are not in line with the research conducted by Ratna and Yuan (2013) which resulted significant differences in mothers' nutrition knowledge after counseling. Therefore, it is concluded that with good knowledge mothers would be able to behave properly and well. Knowledge describes the extent to which respondents apply their knowledge in daily life.

\subsection{Food Composition}

\subsubsection{Distribution of Food Composition in the Meal Box Based on Groups}

Food composition is a food preparation consisted of staple foods, animal proteins, vegetable plant proteins, vegetables and fruits that are brought by the children every day.

The graph below shows the score of changes frequency of the food composition in the meal box based on groups.

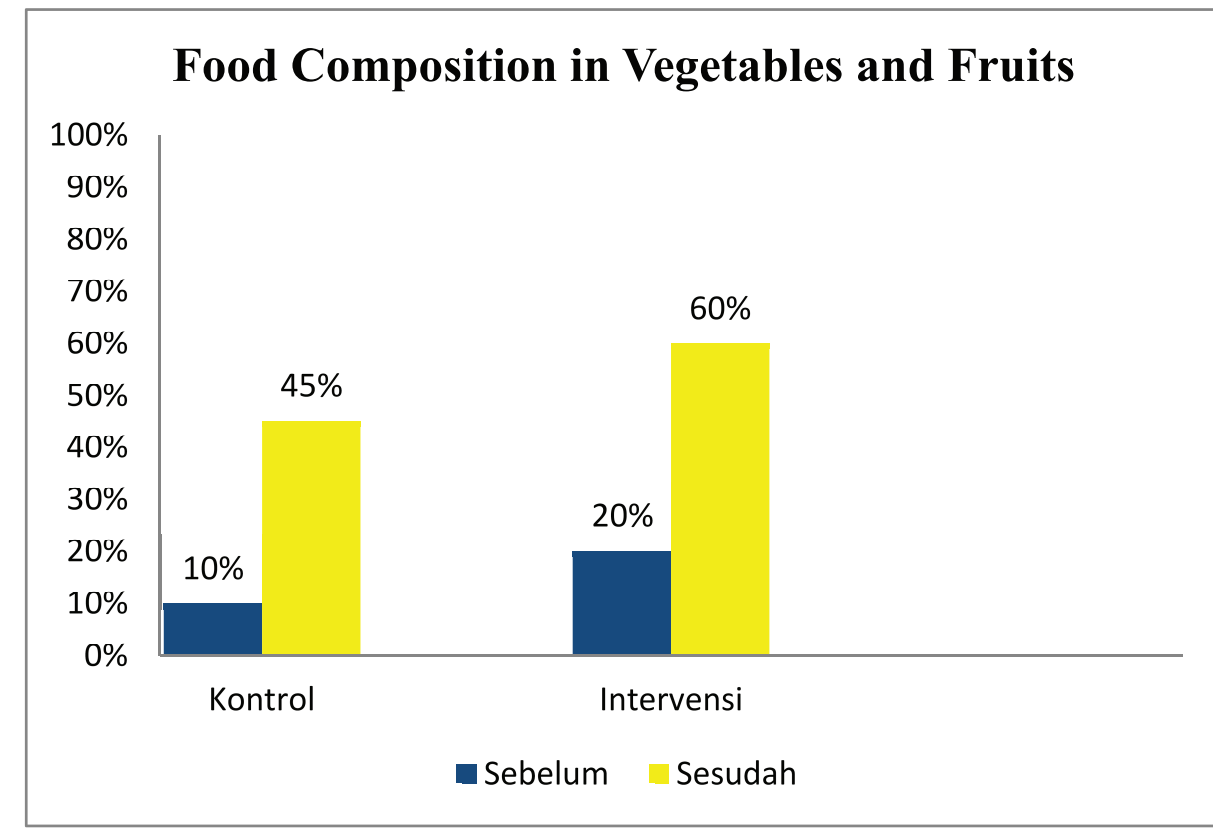

\section{*Control *Intervention \\ *Before *After}

Figure 2: Graph of Frequency Distribution of Composition of Foods in Inter-group Meal Box. 


\subsubsection{The Effect of Training on Modifying Meal Box towards Changes in Food Composition in the Treatment Groups and Control Groups}

TABLE 6: Differences in Food Composition Before and After stock modification training in the Treatment and Control Groups.
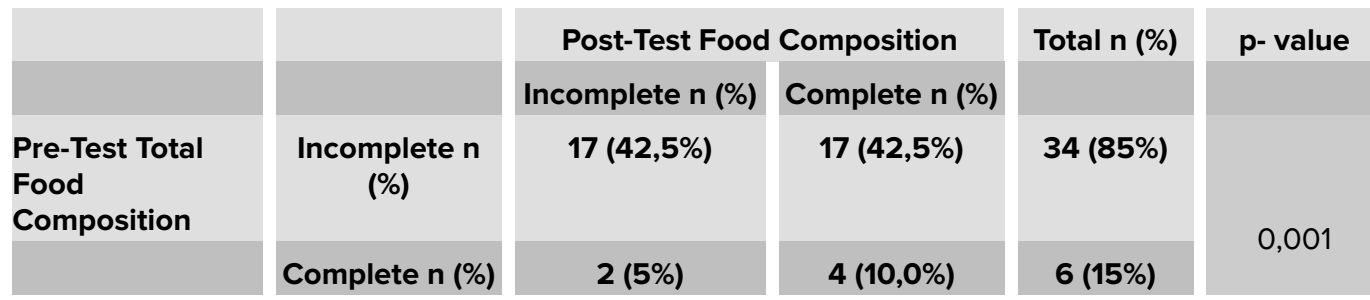

\section{NcNemar Test}

In table 6 the children who carried incomplete food composition before intervention and remained incomplete after the intervention as much as $42.5 \%$, while children who carried incomplete food ingredients before the intervention then become completed after the intervention as much as $42.5 \%$. Then, the child who carried the complete composition of food ingredients before the intervention and becomes incomplete after the intervention was $5 \%$. Then, the child who brought the complete composition of food ingredients before the intervention and remained complete after the intervention was $10 \%$.

The results of the McNemar Test showed significant differences with $p$ value 0.001 $(<0.05)$, so it is concluded that there was an effect of training on food stock modification on food composition brought by preschoolers.

\subsection{Consumption of Vegetables and Fruits in Meal Box Based on Groups}

\subsubsection{Changing in the Consumption of Vegetables and Fruits Scores in Meal Box based on Groups}

According to Notoatmodjo (2010), behavior is the totality of one's understanding and activity, resulted from internal and external factors. However, food consumption consists of information about the type and amount of food consumed by a person at a certain time (Supriasa, 2001). 
The chart below presented the frequency of changing scores in vegetable consumption and in meal box based on groups.

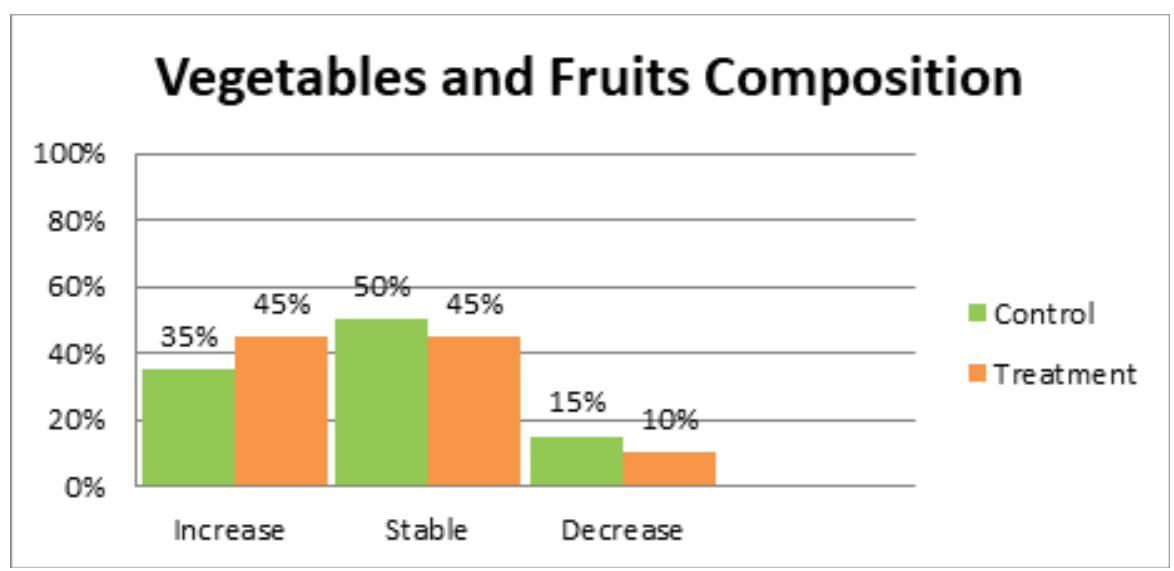

Figure 3: Graph of Frequency Distribution of Changing Scores on Vegetables and Fruits Consumption in Meal Box based on Groups.

On Figure 3, it was found in the treatment group that the increase in vegetable and fruit consumption was higher compared to the control group, which was $45 \%$ since the treatment group got assistance every day and training in modification of supplies. Therefore, there was a change in the mother's behavior when delivering food supplies even though the assistance did not involve the child.

Moreover, there was a decrease in the control group as $15 \%$ because the control group was not given assistance and modifying meal box training so that the mother provided more meals in accordance with the wishes of the child. Therefore, there was no major increase in the consumption of vegetables and fruits.

\subsubsection{The Effect of Modifying Meal Box Training on Vegetables and Fruits Consumption in the Treatment Groups and Control Groups}

TABLE 7: Differences in Vegetables and Fruit Consumptions in Meal Box Before and After Extension in the Treatment Group and Control Group.

Variable
Consumption of
Vegetables and
Fruits

\begin{tabular}{|l|}
\hline Group \\
\hline Treatment \\
\hline Control \\
\hline
\end{tabular}
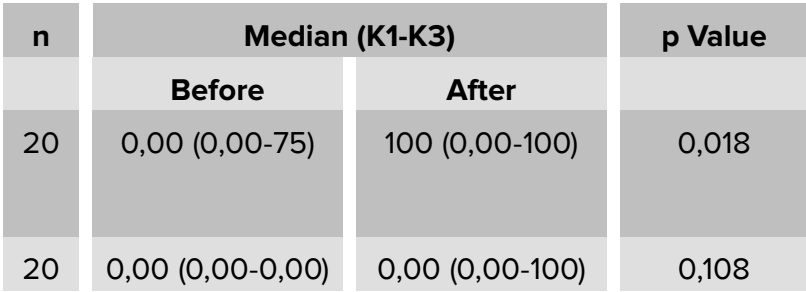


\section{Wilcoxon Test}

TABLE 8: Differences in Vegetables and Fruits Consumption in Meal Box After Training for Modifying Meal Box based on Groups.

\begin{tabular}{|l|c|c|c|c|}
\hline Variable & Group & N & Median (K1-K3) & p Value \\
$\begin{array}{l}\text { Consumption of } \\
\begin{array}{l}\text { Vegetables and } \\
\text { Fruits }\end{array}\end{array}$ & Treatment & 20 & $100(0,00-100)$ & \\
\hline & Control & 20 & $0,00(0,00-100)$ & 0,270 \\
\hline
\end{tabular}

\section{Mann Whitney Test}

In table 7, there was an increase in vegetables and fruits consumption in the treatment group before and after the intervention. The Wilcoxon test results showed a significant difference with $p$ value $0.018(<0.05)$, whereas in the control group there was no difference in vegetable and fruit consumption before and after the intervention $p$ value of $0.0108(<0.05)$.

\section{Discussion}

\subsection{Characteristics of Respondents Before the Intervention}

The numbers of family members in the intervention and control groups were typically consisted of 4 family members (having 2 children). According to Gabriel (2008), the number of families influences the level of attention in fulfilling the needs of food. It shows that the more number of family members need more food to be consumed. Thus, the distribution of food in the family is smaller.

The average score of respondents' nutritional knowledge was 80-85; this shows that the intervention group and the control group have good knowledge.

Before the intervention was given, the average consumption of vegetables and fruit in the intervention group and the control group was $20-25 \%$ of the total meal box consumed.

\subsection{Knowledge on Nutrition}

The increase knowledge in the control group occurred because at the beginning of the study the control group had a higher knowledge score than the treatment group. 
Besides, in the control group some respondents understood that they will fill in the questionnaire again. The respondents were enthusiastic about the research conducted, so that before answering the questions, the respondents recalled the material that had been given in the same counseling as the treatment group.

This is in accordance with the research conducted in Bugenvil PAUD Bekasi, indicating that there is a difference in mother's knowledge after respondents received information through electronic media and health education (Aprilila, 2013, Mette. R. 2006, Dena R.H. 2008)

The decrease in the score of mother's knowledge in the control group occurred because in the control group there was no assistance or further intervention carried out every day, they only received counseling at the beginning before the intervention. According to Mardikanto in Rahmawati (2007), a message or information received by someone will still be remembered within 10-14 days after the message was delivered.

\subsection{Food Composition}

In Figure 2, the Chi-Square test obtained result as p value of $0.527(<0.05)$, after being intervened for the children who brought more complete meals with vegetables and fruit in the treatment group (60\%) compared to the control group (45\%).

The treatment group experienced improvement in since the researchers provided assistance by observing the meal box brought by the children, to clarify between the theories taught with the real form of food being brought. The counseling that the researcher gave to the mother was purposed to prepare food according to the recommended preschoolers' meal box composition. Before the intervention given, the mother supplies children with carbohydrate sources, namely potatoes, noodles, rice and potatoes and other sources of animal protein, namely nuggets, sausages, and chicken. Although the mentoring was carried out only on the mother, and did not involve the child, this assistance was reinforcement after an intervention being given so that the mother not only increases her knowledge but can apply it to the meal box brought by their child. Hull (1951) stated the strengthening process as a function of repetition or appreciation in the development of information maintenance so that it can change the habits of everyday behavior.

Based on the results of the research conducted at Pengayoman Kindergarten, there was an increase after an assistance carried out every day by the researchers. Before the intervention, the composition of food ingredients in children's meal box was incomplete; 
most mothers only brought food such as light snacks, rice with nuggets, and UHT milk. Then, throughout every day assistance, after the counseling was given, there was a change in score 2 which means completed. Some mothers have provided food consisting of staple foods, animal protein, vegetable protein, vegetables, and small portions of fruit.

The result of this research is in line with the research of Apiliani (2010) in Bogenvil Preschool, Bekasi City, which showed that rice and side dishes were food supplies that were commonly carried out by the sample of $20 \%$. From the variant of morning snack (lunch or snack food) samples, it was found that most of the meal box consisted of rice and side dishes and snacks in the form of biscuits. It can be said that morning samples refreshment (food or snack foods) in general has no variant because it did not meet the source of energy, building materials and regulating substances at once.

Based on the results of research conducted at Trisula Kindergarten, there was an increase before and after counseling. Nevertheless, there was no significant change in score in the treatment group. This was because the control group was not experienced assistance. The only intervention provided was counseling and the researcher returned to an observation during the posttest fulfillment.

In their daily lives, children consumed three variations of food, namely rice (93.5\%), vegetables (64.5\%) and meat (64.5\%). It was quite varied but still did not meet the standards of healthy food because there were food groups that did not include fruit (Ogden, 2010). This presented the imbalance in the composition of healthy eating, children consumed more carbohydrates and protein than fiber contained in fruits and vegetables. Although children in their daily lives ate fruits and vegetables but the quantity was in insufficient standard

\subsection{Consumption of Vegetables and Fruits in Meal Box Based on Groups}

Based on the results of research conducted in Pengayoman Kindergarten, the consumption of vegetables and fruits before and after the intervention experienced a good increase since in the treatment group most of the mothers have brought a complete meal with vegetables and fruits. Moreover, after the counseling, mentoring and modification training had been given, the increased consumption of vegetables and fruits in the meal box by $100 \%$. The meal box which was completed and containing vegetables and fruits have been eaten out well by preschoolers. 
Based on the results of the research conducted at Trisula Kindergarten, in the control group, there was no increase in vegetables and fruits consumption before and after the intervention was given because the control group was not given training in modifying meal box such as in the treatment group. Therefore, mothers mostly did not provide complete meal box. Then, there was no assistance carried out every day by the researcher so that the mother prepared meal box according to the child's request, unless they did not eat out the meal. This study is not in line with the research of lana et al (2016) which shows an influence of nutrition counseling on vegetable and fruit consumption in the control group that obtained $p$ value $=0,000$. This research was conducted towards three groups, the groups which resulted significant different namely the group with lecturing group, lecture method group and play with play group.

On table 8 , the results of statistical tests using the Mann Whitney method obtained $p$ value of $0.270(<0.05)$. Consequently it is concluded that there was no significant difference in the average consumption of vegetables and fruits in the treatment and control groups after modification meal box training had been given.

Hence, after training on the meal box modification, there were still mothers who did not provide meal box, including vegetables and fruit. Therefore, the data analysis did not show a significant difference between the two groups.

There was no difference in the average vegetable and fruit consumption in the two groups, due to the influence of other factors, such as the mothers' workload who were too busy so they could not prepare a complete meal in the morning. As a result, many mothers prepared instant food even though the researchers had given training. Both in the control group and the treatment group had the same characteristics in the work of mothers which in both groups the majority of mothers worked as teachers and entrepreneurs where the time they had was limited to prepare children's meal box.

However, the research was conducted 1 month so that there was no significant longterm impact though Budiharto (1999) in the study of Fitriani (2011) argued to measure a person's knowledge between the initial and final evaluation takes 2 weeks, while measuring a person's behavior takes 2 months.

This research is in line with the research of Aminudin et al. (2011) which stated that the Chi Square test results show insignificant influence of interventions on the frequency of mothers of children under five visiting integrated service center (POSYANDU) although the interventions can encourage an increase the frequency of mothers of children under five visiting it (POSYANDU) 
In the research conducted by Lally (2009), typically, it needs 12 weeks to do activities automatically. This means that it takes a longer period of time (12 weeks) to form a person's habit/behavior, although in the European Journal of Social Psychology, he added, the average person is able to adapt to his new behavior within 18-254 days. Henceforth, this research which was conducted for 1 month was not enough to shape a person's behavior.

\section{Conclusion}

There were no differences in characteristics including mother's age, number of family members, preferences for vegetables, preferences for fruits, composition of food ingredients, and consumption of vegetables and fruits in the control group and treatment group before the intervention. Nevertheless, there are differences in the level of knowledge in the control group and the treatment group.

There was a difference in knowledge before and after the intervention in the control and treatment groups. However, after an intervention had been given, there was no significant difference in knowledge in the control group and the treatment group with $p$ value of 0.770 .

There was an increase in the number of respondents who brought meal box full of fruits and vegetables in the treatment group.

There were differences in vegetables and fruits consumption before and after the intervention in the treatment group while there were no differences in vegetables and fruits consumption before and after the intervention in the control group. However, after being given an intervention, there was no significant difference in knowledge in the control group and the treatment group with $p$ value of 0.270 .

\section{References}

[1] RDA, 2013. Recommended Dietary Allowance. Ministry of Health, Republic of Indonesia.

[2] Almatsier, et.al. 2011. Nutrition Through Life Cycle. Jakarta: PT. Gramedia Pustaka IImu

[3] Almatsier, Sunita. 2009. Basic Nutrition. Jakarta : Gramedia Pustaka Utama.

[4] Aprilila, Ulfa. 2013. Quality of Snack on Preschool Children (PAUD Bougenvil), Bekasi. Faculty of Human Nutrition, Institute of Agriculture Bogor. 
[5] D.Upton, P.Upton and C. Taylor. 2012. Fruit and Vegetable Intake of Primary School Children; A Study of School Meal's. Journal of Human Nutrition and Dietetics, 1-6

[6] Daruwati Multiningtyas Siagian. 2017. Fruit and Vegetables Consumption on Children Obesity, Grade $5^{\text {th }}$ and $6^{\text {th }}$ on Pantekosta Elementary School Magelang. Nutrition Program Study, Politecnic of Health, Yogyakarta.

[7] Ministry of Health, Republic of Indonesia. Basic Health Research of Indonesia. 2010.

[8] Ministry of Health, Republic of Indonesia. Basic Health Research of Indonesia 2013.

[9] Ministry of Health, Republic of Indonesia.(2006). Guidelines for implementing stimulation, early detection and intervention of child growth and development at the level of basic health services.

[10] Ministry of Health, Republic of Indonesia. 2008. Basic Health Research of Indonesia 2007.

[11] Ministry of Health, Republic of Indonesia, 2014, Balance Nutrition Guidelines, Directorate of Nutrition. Jakarta.

[12] .Ministry of Health, Republic of Indonesia. 2012. Indonesian health profile. http:// www.depkes.go.id Accessed on February $2^{\text {nd }}, 2018$.

[13] Dewantari, Ni Made dan Ari Widiani. 2011. Fruits and Vegetables Consumption Pattern in School Children. Jurnal Skala Husada.8 (2), 119-125.

[14] Eun Byul Choi et al. 2018. Fruit and Vegetable Intakes in Relation to Behavioral Outcomes Associated With A Nutrition Education Intervention In Preshoolers. Nutrition Research and Practice. 12 (6), 521-526

[15] Firiani, Dianita. 2011. The influence of peer education on clean and healthy living behavior in school age children who are at risk of worm investation on Baru Village, manggar Sub distric, East Belitung. Depok UI.

[16] Gabriel, Angelica. 2008. Relationship between family nutrition awareness and clean and healthy living with nutrional status of under five children in Cikarawang village, Bogor. Program Study of Nutrition, Faculty of Agriculture, Institute of Agrculture Bogor.

[17] Harnack, LJ., et al. 2012. Results from an experimental trial at a head start center to evaluate toe increase fruit and vegetable intake of preschool aged children. Nutrition Journal of Behavioral Nutrition and Physical Activity, 9:51

[18] Hull, C. L.1943. Principles of behavior: An introduction to behavior theory. New York: Appleton-Century-Crofts. Hull, C. L. (1951). Essentials of behavior. Westport, CT: Greenwood Press. 
[19] lana Tresia A.Sibagariang, ALbiner Siagian, dan Fitri Ardiani (2016). The Effect of Fruit and Vegetable Counseling With Two Method on Knowledge and Attitude of Vegetable and Fruit Consumption in Elementary School Children, Medan Deli District, 2018. Sumatera Utara : Faculty of Public Health, University of Sumatera Utara, Medan.

[20] Jayani, Santi, et al. 2011. The Effect of the Frequency of Test on Long Term Reading Memory in High School Students.. Jurnal Psikologi, 6 (2), 430-441.

[21] Kirsten A.G, et al 2014. Fruit and Vegetablee Intake During Infancy and Early Childhood. Pediatrics. 134 (1), S63-S69

[22] Lally, Phillippa, et al. 2009. Research Article: How Are Habits Formed: Modelling Habit Formation In The Real World. European Journal of Social Psychology, Eur. J. Soc. Psychol. 40, 998-1009. London: University College London

[23] Meliala, Hardianti 2014. Study on Mother's Behavior in Preparing Food and Their Contribution to The Nutritional Adequacy of Preschool Children in Aisyiyah Kindergarten, Tanjung Sari, Medan. Departement Nutrition of Public Health, University of Sumatera Utara.

[24] Namyota.C and Sirikulchayanonta.C. 2018. Promoting Local Vegetable and Fruit Consumption among Pre-school Children at A Child Development Day Care Centre. International Food Research Journal, 25 (2), 472-480

[25] Notoatmodjo, Soekidjo. 2010. Health Promotion Theory and Application.. Jakarta: PT Rineka Cipta.

[26] Nuryanto, Adriyan Pramono, Niken Puruhita, Siti Fatimah Muis, 2014. The Effect of Nutrition Education on Knowledge and attitude of elementary school children. Program Study Nutrition, Faculty of Medicine University of Diponegoro. (ISSN : 18584942) Vol. 3, No. 1, Desember 2014: 32-36

[27] Pem, Dhandevi dan Rajesh Jeewon. 2015. Review Article: Fruit and Vegetable Intake: Benefits and Progress of Nutrition Education Interventions. Iran J Public Health, Vol. 44, No. 10, Oct 2015, pp. 1309-1321.

[28] Rahmawati, Ira dkk. 2007. The Effect of Counseling With Audio Visual Media on Increasing Knowledge, Attitudes and Behavior of Mother of Malnourished Under Five Children in West Kotawaringin Distric, Province Central Kalimantan. Jurnal Gizi Klinik Indonesia 4(2), 69-77.

[29] Ratna Wardani dan Puan Prianggajati,2013. Study on Factors That Influence Mother Food Choices in Family in Rt 25 Rw 09, Tirtoudan, Subdistric Tosaren. School of Health Sciences. Journal Eduhealth, vol 3 No. 2 Sept. 2013. 
[30] Santoso, A. 2011. Function of Dietary Fiber on Health

[31] Soetjiningsih. Child Growth and Development. Jakarta: Medical EGC.

[32] Shriver. L.H. et al. 2018. Increasing Fruit and Vegetable Intake in Low-Income Minority Children; African American Mothers As Experts on Effective Strategies and Barrier to FV. Journal of Child Adolesc Health, 2 (1), 13-21

[33] Supriasa, I Dewa Nyoman. 2001. Nutritional Assessment. Jakarta: EGC.

[34] Zurida, Reni. 2015. Dietary Risk Factors and Their Relationship to Heart Disease in Adult Men and Women in Province of Lampung. Department of Nutrition. Faculty of Medicine, University of Lampung, Province Lampung. 